\title{
Influence of edaphoclimatic conditions on stem production and stem morphological characteristics of 10 European hemp (Cannabis sativa L.) varieties
}

\author{
Marko FLAJŠMAN ${ }^{1,2}$, Darja KOCJAN AČKO ${ }^{1}$
}

\begin{abstract}
Received February 19, 2020; accepted April 30, 2020.
Delo je prispelo 19. februarja 2020, sprejeto 30. aprila 2020
\end{abstract}

Influence of edaphoclimatic conditions on stem production and stem morphological characteristics of 10 European hemp (Cannabis sativa $\mathrm{L}$.) varieties

Abstract: Six dioecious (Antal, KC Dóra, Kompolti hibrid TC, Monoica, Tiborszallasi and Tisza) and four monoecious (Fedora 17, Futura 75, Santhica 27 and USO 31) European hemp varieties were sown at a density of 300 viable seeds per $\mathrm{m}^{2}$ and a row spacing of $12.5 \mathrm{~cm}$ in a three-year field trial (2017-2019) to evaluate the yield of the stems (fresh and dry) and some other biometric characteristics of the stems. No pesticides were used during plant growth to suppress weeds, diseases and pests. The highest yield of fresh and dry stems was achieved by the variety Antal with $12.3 \mathrm{t} \mathrm{ha}^{-1}$ and $5.3 \mathrm{t} \mathrm{ha}^{-1}$, respectively, followed by the varieties Futura 75 and Tiborszallasi. The lowest yields of fresh and dry stems were recorded for the monecious variety USO 31 (6.0 and $2.6 \mathrm{t} \mathrm{ha}^{-1}$ ). In general, dioecious varieties had higher and thicker stems than monoecious varieties. The year of production had a highly significant impact on all variables, in particular on the proportion of weed biomass, which was the highest in 2019 (77.2 \%), when weather conditions were most unfavourable for hemp cultivation. The correlation analysis between fresh/dry stem yields and weed biomass was highly negative $(-0.85$ and -0.83$)$ and strongly statistically significant $(p<0.001)$, indicating the issue related to weed management.

Key words: hemp; Cannabis sativa L.; yield of stem; weather conditions; weeds
Vpliv pedo-klimatskih razmer na pridelek in morfološke lastnosti stebel 10 evropskih sort navadne konoplje (Cannabis sativa $\mathrm{L}$. .)

Izvleček: Šest dvodomnih (Antal, KC Dóra, Kompolti hibrid TC, Monoica, Tiborszallasi in Tisza) in štiri enodomne (Fedora 17, Futura 75, Santhica 27 in USO 31) evropske sorte navadne konoplje smo sejali pri gostoti 300 kalivih semen na $\mathrm{m}^{2}$ na medvrstno razdaljo $12,5 \mathrm{~cm}$ v letih 2017 do $2019 \mathrm{z}$ namenom ovrednotiti pridelek svežih in suhih stebel ter določiti nekatere druge morfološke lastnosti stebel. Fitofarmacevtska sredstva za zatiranje plevelov, bolezni ali škodljivcev med rastjo rastlin niso bila uporabljena. Največji pridelek svežih in suhih stebel je dosegla sorta Antal, in sicer 12,3 $\mathrm{t} \mathrm{ha}^{-1}$ in 5,3 $\mathrm{t} \mathrm{ha}^{-1}$, sledili sta sorti Futura 75 in Tiborszallasi. Najmanjši pridelek svežih in suhih stebel je dosegla enodomna sorta USO $31(6,0$ and $\left.2,6 \mathrm{t} \mathrm{ha}^{-1}\right)$. Dvodomne sorte so imele v povprečju višja in debelejša stebla od enodomnih sort. Leto pridelave je imelo velik vpliv na vse spremenljivke, še posebno na odstotek plevela v skupni biomasi, ki je bil največji v letu 2019 (77,2 \%), ko so bile vremenske razmere najmanj ugodne za pridelavo navadne konoplje. Korelacijska analiza med pridelkom svežih/suhih stebel in odstotkom biomase plevela je bila negativna $(-0,85$ in $-0,83)$ ter močno statistično značilna $(p<0,001)$, kar je pokazalo na problem plevelov pri pridelavi navadne konoplje.

Ključne besede: navadna konoplja; Cannabis sativa L.; pridelek stebel; vremenske razmere; pleveli 


\section{INTRODUCTION}

From the 16th to the 18th century, hemp (Cannabis sativa L.) was the most important fibre crop in Europe, together with flax (Struik et al., 2000). The hemp stems have been produced because of the long and strong bast fibres traditionally used in the textile and paper industry (Mandolino \& Carboni, 2004). Due to the high tensile strength and excellent fineness of hemp fibres, new applications are emerging today, e.g. in geotextiles and biocomposites (Schäfer \& Honermeier, 2006; Salentijn et al., 2015). The woody part of the hemp stem is called hurd, also shive, and is used for animal bedding, pulp production and the manufacture of building materials, e.g. hemp concrete (Karus \& Vogt, 2004; Elfordy et al., 2008). This versatile use of hemp stems makes hemp one of the oldest non-food crops used worldwide (Schultes, 1970).

The cultivation of hemp is less demanding compared to some other crops (e.g. maize and wheat). Hemp can be grown with minimal or even no pesticides. Due to its rapid juvenile growth, the plant itself successfully suppresses weeds. It could be grown in a relatively narrow crop rotation and has a low fertilization requirement (van der Werf, 1994). However, hemp is a crop whose cultivation is very much influenced by soil and weather conditions.

As far as climatic conditions are concerned, a humid atmosphere is most suitable for hemp cultivation when growing for stem and fibres (Ranalli, 1999). For the production of one kg dry matter hemp needs 300-500 1 water. During the vegetative growth phase $250-300 \mathrm{~mm}$ of rainfall is required and a total of $500-700 \mathrm{~mm}$ of water for the whole season. Precipitation in June and July has a very large influence on plant growth when the seeds are sown in late spring (Bócsa \& Karus, 1998). Excess or lack of water in the early stages of development is crucial for yield formation (Struik et al., 2000).

Edaphically, hemp grows well in deep or medium deep soils with a sandy loam structure. Clay loam, heavy clay and sandy soils are less suitable for hemp cultivation (Amaducci et al., 2015). Highly fertile soil for stem production is soil on which a potential yield of $10000 \mathrm{~kg}$ dry matter per ha can be achieved (Bócsa \& Karus, 1998).
This type of soil is well drained with a $\mathrm{pH}$ around 6.0 (Barron et al., 2003).

The main goal of hemp stem production is usually the extraction of bast fibres. The fibre yield is a product of fibre content and stem yield (Berenji et al., 2013). Moreover, fibre yield is also directly related to stem yield (Hennik, 1994). The fibre content in the stem is primarily influenced by the genotype, e.g. it is advisable to use varieties with a longer vegetative cycle for stem production (Struik et al., 2000). On the other hand, stem yield could be influenced by the use of different agricultural techniques (time of sowing, sowing density, fertilisation, time of harvest, etc.) (Amaducci et al., 2008). However, the edaphoclimatic and seasonal growing conditions could not be influenced by labour and therefore have a decisive influence on the agronomic performance of hemp.

The aim of the study was to evaluate the agronomic performance of 10 different European hemp varieties in terms of stem production during the three-year growing period. Secondly, the influence of growing conditions on stem characteristics and proportion of weed biomass was also evaluated. Finally, a correlation analysis was performed to gain insight into the relationships between the variables studied.

\section{MATERIAL AND METHODS}

\subsection{EXPERIMENTAL SITE AND SOIL CHARAC- TERISTICS}

The field experiments were carried out at Ljubljana (Biotechnical Faculty), Slovenia $\left(46^{\circ} 3^{\prime} \mathrm{N}, 14^{\circ} 30^{\prime}\right.$ E, altitude $295 \mathrm{~m}$ ) during the 2017-2019 growing seasons. On the test site the soil was medium deep and hydromeliorated with a texture of $31.9 \%$ clay, $43.2 \%$ silt and $24.9 \%$ sand. The soil fertility characteristics for each year of the field trials are shown in the Table 1.

\subsection{VARIETIES USED AND THE DESIGN OF THE FIELD TRIAL}

10 commercial hemp varieties used in this study are

Table 1: Chemical properties of the soil at the test site

\begin{tabular}{lllll}
\hline Year & $\begin{array}{l}\mathrm{pH} \\
\text { in KCl }\end{array}$ & $\begin{array}{l}\mathrm{P}_{2} \mathrm{O}_{5} \\
(\mathrm{mg} / 100 \mathrm{~g} \text { soil })\end{array}$ & $\begin{array}{l}\mathrm{K}_{2} \mathrm{O} \\
(\mathrm{mg} / 100 \mathrm{~g} \text { soil })\end{array}$ & $\begin{array}{l}\text { Organic matter } \\
(\%)\end{array}$ \\
\hline 2017 & 6.6 & 15.2 & 16.3 & 3.6 \\
2018 & 6.8 & 19.5 & 15.9 & 3.9 \\
2019 & 6.9 & 11.9 & 9.3 & 4.5 \\
\hline
\end{tabular}


Table 2: Some characteristics of hemp varieties used in field trials

\begin{tabular}{|c|c|c|c|c|}
\hline Variety & Origin & Sexual type & Vegetative cycle* & Applications \\
\hline Antal & Hungary & Dioecious & Late & Flowers/CBD \\
\hline Fedora 17 & France & Monoecious & Early & Seed/CBD/fibre \\
\hline Futura 75 & France & Monoecious & Late & Seed/CBD/fibre \\
\hline KC Dóra & Hungary & Dioecious & Late & Seed/CBD/fibre \\
\hline Kompolti hibrid TC & Hungary & Dioecious & Medium & Fibre \\
\hline Monoica & Hungary & Dioecious & Medium & Seed/CBD/fibre \\
\hline Santhica 27 & France & Monoecious & Medium & Seed/fibre \\
\hline Tiborszallasi & Hungary & Dioecious & Late & Seed/fibre \\
\hline Tisza & Hungary & Dioecious & Late & Seed/fibre \\
\hline USO 31 & Ukraine & Monoecious & Early & Seed/fibre \\
\hline
\end{tabular}

${ }^{*}$ Early < 125 days; Medium < 135 days; Late $<145$ days

listed in the Table 2. Data on variety characteristics were obtained from Flajšman et al. (2018) and Ihempfarms (2019).

The previous crops for the first, second and third year of the field trial were soybeans, maize and lupines, respectively. Every year, the residues of the previous crops were ploughed in autumn and the field was left fallow over the winter. Before sowing the field was fertilized with $500 \mathrm{~kg} \mathrm{ha}^{-1}$ of NPK 0:14:28 and $260 \mathrm{~kg} \mathrm{ha}^{-1}$ of calcium ammonium nitrate $(27 \% \mathrm{~N})$. No additional fertilizers were used during the growth of the plants. No pesticides were used to suppress weeds, diseases and pests. Sowing was carried out in May (4 May 2017, 29 May 2018 and 8 May 2019) with a Wintersteiger plot seeder. The experiment was designed as a randomized, complete block experiment with three replications. The experimental plot size was $18 \mathrm{~m}^{2}(6 \times 3 \mathrm{~m})$, with a plant density of 300 viable seeds per $\mathrm{m}^{2}$ and a row spacing of $12.5 \mathrm{~cm}$. The harvests were preformed manually in August (17 August 2017, 28 August 2018 and 22 August 2019). For each plot, only the inner $4 \mathrm{~m}^{2}$ were used to determine the variables. First, the total biomass (hemp plants + weeds) was cut at the ground and weighed. Secondly, the biomass of the first $\mathrm{m}^{2}$ was separated and weighed on the hemp plants and weeds. The weight data were used to determine the proportion (percentage) of weed biomass in the total biomass and the yield of fresh stems. Thirdly, the hemp plants were separated from first $\mathrm{m}^{2}$ by sexual type (only for dioecious varieties) and counted to determine the sex ratio and number of plants per $\mathrm{m}^{2}$ at harvest. Fourthly, 25 plants per sexual type (male, female and/or monoecious) of the same $\mathrm{m}^{2}$ were randomly selected for the determination of mass, height and stem diameter. Finally, the same 25 plants per sexual type were dried at $55^{\circ} \mathrm{C}$ until

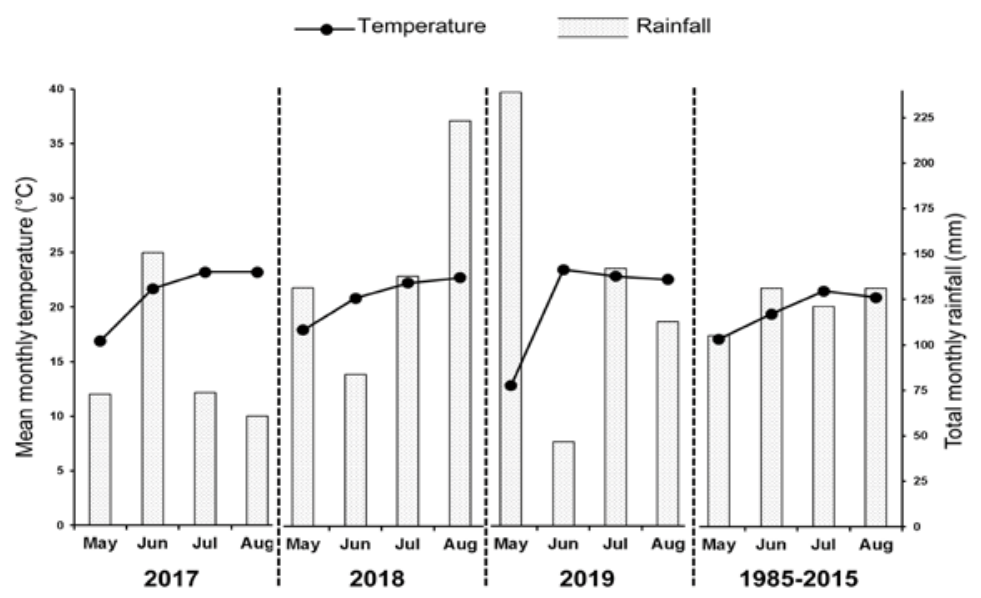

Figure 1: Mean monthly temperature and total monthly precipitation from May to August for the field experiments from 2017-2019 and the long-term average (1985-2015). The association between precipitation and temperature on the y-axes is $6 \mathrm{~mm}: 1^{\circ} \mathrm{C}$, which is adapted to the Slovenian climate conditions. If the temperature curve is higher than the columns, a slight drought is expected. 
constant mass was achieved for the determination of the yield of dry stems.

\subsection{WEATHER CONDITIONS}

Temperatures were above the long-term average in almost all years and months. Notable exceptions were May 2019, when the average temperature was only $12.9{ }^{\circ} \mathrm{C}$, compering to $17.2^{\circ} \mathrm{C}$ of the long-term average, and June 2019, when the average temperature was $4{ }^{\circ} \mathrm{C}$ above the long-term average. The arrangement of the precipitation showed more variation regarding the month and year of the field trials. The lack of precipitation was the highest in June 2019 and August 2017, when only the amount $35 \%$ and $46 \%$ of the long-term average occurred. On the other hand, the surplus of precipitation was the highest in May 2019 and August 2018, with the amount of $227 \%$ and $170 \%$ of the long-term average precipitation for these months, respectively (Figure 1).

\subsection{STATISTICAL ANALYSES}

The data of the variables studied over three years were first subjected to a combined analysis of variance (ANOVA). Year taken as a factor, variety and year $\times$ variety interaction were considered fixed effects and determined to be significant if $p<0.05$. Replications were considered random effects. Significant differences in the mean values given by ANOVA were evaluated using the Duncan test $(\alpha=0.05)$. The data were analysed with the package 'agricolae' in the R-Software version 3.2.5 (R Core Team, 2016). Furthermore, the analysis of the correlation between the response variables was also calculated using the same R-package. The graphics were drawn by the Microsoft Excel programme.

\section{RESULTS AND DISCUSSION}

\subsection{YIELD OF STEMS}

The yields of fresh and dry stems were significantly influenced by the year $(p<0.001)$, but the variety had no statistically significant effect $(p=0.0889$ for the yield of fresh stems and $p=0.0729$ for the yield of dry stems). There was no interaction between the two factors. The highest average yields of fresh and dry stems were achieved by the Antal variety with $12.3 \mathrm{t} \mathrm{ha}^{-1}$ and $5.3 \mathrm{t} \mathrm{ha}^{-1}$, respectively, and Futura 75 with $11.4 \mathrm{t} \mathrm{ha}^{-1}$ of fresh and $4.7 \mathrm{t} \mathrm{ha}^{-1}$ of dry stems. The lowest yields of fresh and dry stems were measured for the varieties Santhica $27\left(6.7 \mathrm{tha}^{-1}\right.$ and $\left.2.6 \mathrm{tha}^{-1}\right)$ and USO $31\left(6.0 \mathrm{tha}^{-1}\right.$ and $2.6 \mathrm{t} \mathrm{ha}^{-1}$ ) (Figure 2). The influence of the growing season and environmental characteristics can be summarised with the Futura 75 variety, which has been used in many field trials in Europe. In Latvia (Tang et al., 2016), for example, the yield of dry steam of this variety reached $20.3 \mathrm{t} \mathrm{ha}^{-1}$, whereas in France the stem yield was only $2.8 \mathrm{t} \mathrm{ha}^{-1}$ (Tang et al., 2017). In two-year field trials by Amaducci et al. (2008), the variety Futura 75 (10.7 $\mathrm{t} \mathrm{ha}^{-1}$ - $13.1 \mathrm{t} \mathrm{ha}^{-1}$ ) has outyielded the variety Tiborszallasi $\left(8.4 \mathrm{t} \mathrm{ha}^{-1}-10.6 \mathrm{t} \mathrm{ha}^{-1}\right)$ on dry stems. Cosentino et al. (2012) also tested these varieties in a two-year field trial, in which the average yield of the dry stems of Futura 75 was around $4 \mathrm{tha}^{-1}$ and $6 \mathrm{t} \mathrm{ha}^{-1}$ for Tiborszallasi. In our field trial, the yields of the two mentioned varieties were comparable (average $4.7 \mathrm{t} \mathrm{ha}^{-1}$ ) with only $2.5 \%$ yield difference to the benefit of the Tiborszallasi (Figure 2).

Baldini et al. (2018) tested many different monoecious varieties. The two-year averages (2016 and 2017) of the dry stem yields were 6.0 (3.8), 4.0 (2.6), 7.7 (4.2), 7.8 (4.6) and 8.3 (4.7) $\mathrm{t} \mathrm{ha}^{-1}$ for the varieties Fedora 17, USO 31, KC Dora, Monoica and Futura 75, respectively. In brackets are shown the average values of the dry stem yield from our study and lower yields are observed. Intriguingly, when comparing only the common year 2017, the yields of Fedora $17\left(8.4 \mathrm{t} \mathrm{ha}^{-1}\right)$, USO $31\left(5.0 \mathrm{t} \mathrm{ha}^{-1}\right)$, KC Dora $\left(7.6 \mathrm{t} \mathrm{ha}^{-1}\right)$, Monoica $\left(8.6 \mathrm{t} \mathrm{ha}^{-1}\right)$ and Futura 75 $\left(8.4 \mathrm{t} \mathrm{ha}^{-1}\right)$ from our study differ only slightly from those of Baldini et al. (2018). However, poor weather conditions in the subsequent years 2018 and 2019 led to a decrease in average stem yields in this study (see below).

Dioecious varieties are more suitable for stem production because of the quantity and quality of the fibres (Bosca, 1999). In this trial, the average yield of dry stems of six dioecious varieties $\left(4.6 \mathrm{t} \mathrm{ha}^{-1}\right)$ was $35 \%$ higher than the average yield of four monoecious varieties (3.4 tha $\left.{ }^{1}\right)$. In addition, varieties that start flowering later and have a longer vegetative cycle are more suitable for stem production in terms of yield, since the accumulation of dry matter in the stems decreases very rapidly after the start of flowering (Struik et al., 2000). In our threeyear field trial, five early or medium varieties $\left(3.5 \mathrm{t} \mathrm{ha}^{-1}\right)$ achieved only $74 \%$ of the dry stem yield of five late varieties $\left(4.7 \mathrm{t} \mathrm{ha}^{-1}\right)$. Similarly, the dioecious varieties yielded a higher yield dry stems than the monoecious varieties in the study by Cosentino et al. (2012).

The growing season had a very important influence on the stem yields. The highest average yield of fresh $\left(17.1 \mathrm{tha}^{-1}\right)$ and dry $\left(7.6 \mathrm{tha}^{-1}\right)$ stems was achieved in 2017, followed by 2018, and the lowest yield of fresh $\left(2.7 \mathrm{t} \mathrm{ha}^{-1}\right)$ and dry $\left(1.1 \mathrm{t} \mathrm{ha}^{-1}\right)$ stems happened in 2019. Tang et al. (2016) conducted an extensive study with 14 commercial hemp varieties in four different European 


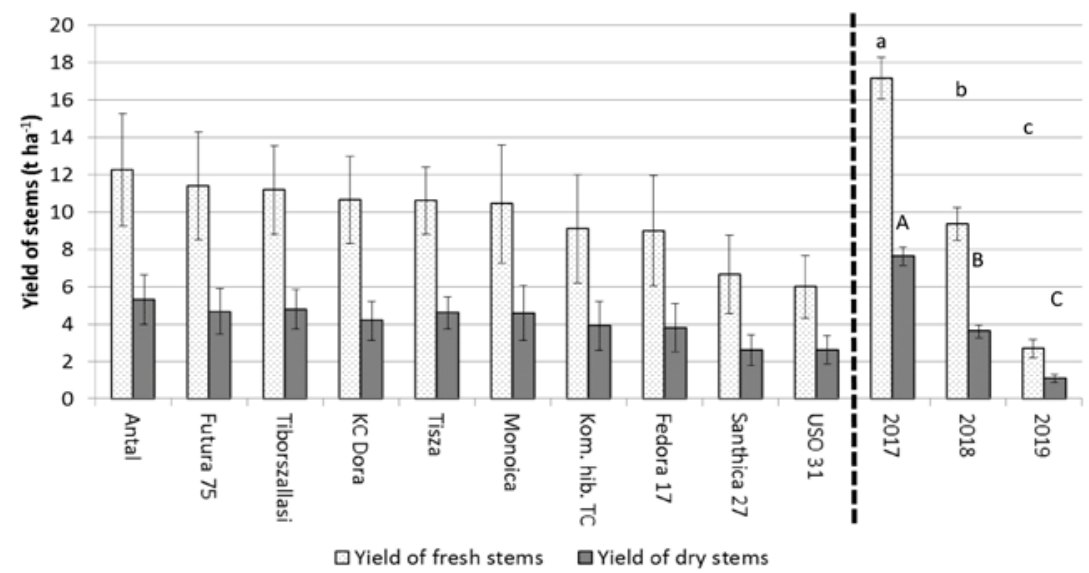

Figure 2: The yield of fresh and dry stems is given as an average by factor variety and as an average by factor year. The lower case letters indicate statistically significant differences in yield of fresh stems and the upper case letters indicate statistically significant differences in yield of dry stems. The main factors (variety and year) are separated by the dotted line and different letters (small or capital) indicate the differences within factor year. Error bars indicate standard errors of the mean values

countries (Latvia, Czech Republic, France and Italy). The yield of dry stems varied considerably among varieties and also among locations, e.g. the yield of dry stems increased from $8.3 \mathrm{t} \mathrm{ha}^{-1}$ in France to $19.5 \mathrm{t} \mathrm{ha}^{-1}$ in Latvia for the variety Tiborszallasi and from $7.3 \mathrm{t} \mathrm{ha}^{-1}$ (Czech Republic) to $22.1 \mathrm{t} \mathrm{ha}^{-1}$ (Latvia) for the variety KC Dora. Although their research was not multiyear trial, the differences in growing environments had a huge impact on the performance of the hemp varieties.

\subsection{BIOMETRIC CHARACTERISTICS OF PLANTS AND OTHER MEASUREMENTS}

Although the same sowing density was used for all varieties in all years, both factors (the year and the variety) but not their interaction influenced the number of plants at harvest. The effect of variety was not statistically significant ( $p=0.0557)$ and 107 plants $\mathrm{m}^{-2}$ (Kompolti hibrid TC) up to 240 plants $\mathrm{m}^{-2}$ (Tisza) were observed (Table 3 ). The proportion of male plants in the dioecious varieties ranged from $32.0 \%$ to $48.8 \%$ (data not shown). Amaducci et al. (2008) reported that plant density together with harvest time is the most important parameter determining fibre production. Mediavilla et al. (2001) found that 170 plants $\mathrm{m}^{-2}$ is typical density for fibre production for Central Europe. On the other hand, Amaducci et al. (2002) stated that 90 to 100 plants $\mathrm{m}^{-2}$ represents an optimal density for stem production. In our three-year field trial, the year of production had a statistically significant influence $(p<0.001)$ on the number of plants at harvest, with the first year showing the highest number (304 plants $\mathrm{m}^{-2}$ ) and the second year the lowest (108 plants $\mathrm{m}^{-2}$ ). The seasonal effect on the number of plants at harvest was also recorded elsewhere (Cromack, 1998; Struik et al., 2006).

The proportion of weed biomass was significantly influenced by both factors, but not by their interaction. The highest average percentage of weed biomass was found for the variety Santhica 27 (51.3\%) and the lowest for the variety Tisza $(27.9 \%)$. The year had a very strong influence on the proportion of weed biomass $(p<0.001)$; the highest percentage was found in 2019 (77.2 \%). On the contrary, the average percentage of weed biomass was very low in 2017 (7.6 \%). Hemp is known for its ability to suppress weeds independently due to its rapid growth and canopy closure (Kraenzel et al., 1998). This assertion was only confirmed in the first year of our trials. In the second year, and especially in the third year, the hemp plants could not overcome the weeds and its biomass increased significantly.

The plant height differed significantly between varieties $(p<0.01)$ where the stem diameter did not. On the other hand, both variables were statistically significantly influenced by the year of production. For neither of these two variables, no interaction between the factors was found. The highest variety was Antal with an average height of $137.7 \mathrm{~cm}$, followed by Tiborszallasi $(130.3 \mathrm{~cm}$ ) and Tisza $(128.9 \mathrm{~cm})$. The lowest varieties were Fedora 17 $(101.6 \mathrm{~cm})$, USO $31(90.1 \mathrm{~cm})$ and Santhica $27(86.5 \mathrm{~cm})$. In 2017 the plants were the highest with an average height of $150.0 \mathrm{~cm}$. The plants were more than twice as small in 2019, averaging $74.3 \mathrm{~cm}$. The average stem diameter did not vary from variety to variety (average $3.96 \mathrm{~mm}$ ), but the influence of the year of production was statistically significant $(p<0.01)$, when in 2018 the stems were thickest $(4.73 \mathrm{~mm})$ and in 2019 the stems were thinnest $(3.15 \mathrm{~mm})$ (Table 3). Plant height and stem diameter are primar- 
Table 3: Influence of variety and year on the average number of plants per $\mathrm{m}^{2}$ at harvest, the proportion of weed biomass, the average plant height and the average stem diameter

\begin{tabular}{|c|c|c|c|c|c|c|c|}
\hline Variety & $\begin{array}{l}\text { Number of plants per } \\
\mathrm{m}^{2} \text { at harvest }\end{array}$ & $\begin{array}{l}\text { Proportion of weed } \\
\text { biomass (\%) }\end{array}$ & & $\begin{array}{l}\text { Plant height } \\
(\mathrm{cm})\end{array}$ & & $\begin{array}{l}\text { Stem diameter } \\
(\mathrm{mm})\end{array}$ & \\
\hline Tisza & $240 \pm 32$ & $27.9 \pm 07.5$ & c & $128.9 \pm 08.7$ & $\mathrm{ab}$ & $4.03 \pm 0.20$ & \\
\hline Fedora 17 & $216 \pm 39$ & $33.7 \pm 11.2$ & $a b c$ & $101.6 \pm 15.1$ & $\mathrm{bc}$ & $3.81 \pm 0.32$ & \\
\hline Tiborszallasi & $211 \pm 29$ & $33.2 \pm 10.4$ & bc & $130.3 \pm 12.2$ & $\mathrm{ab}$ & $4.02 \pm 0.30$ & \\
\hline Antal & $194 \pm 43$ & $36.5 \pm 11.0$ & $a b c$ & $137.7 \pm 16.1$ & $\mathrm{a}$ & $4.19 \pm 0.36$ & \\
\hline Monoica & $188 \pm 27$ & $38.2 \pm 38.2$ & $a b c$ & $125.1 \pm 17.9$ & $\mathrm{ab}$ & $4.02 \pm 0.42$ & \\
\hline USO 31 & $181 \pm 28$ & $50.4 \pm 11.9$ & $\mathrm{a}$ & $090.1 \pm 10.4$ & c & $3.30 \pm 0.32$ & \\
\hline KC Dora & $175 \pm 32$ & $31.1 \pm 10.4$ & $\mathrm{bc}$ & $124.1 \pm 13.3$ & $a b$ & $4.28 \pm 0.32$ & \\
\hline Futura 75 & $175 \pm 31$ & $34.0 \pm 11.6$ & $\mathrm{bc}$ & $121.7 \pm 17.8$ & $a b$ & $4.06 \pm 0.46$ & \\
\hline Santhica 27 & $174 \pm 40$ & $51.3 \pm 12.1$ & $\mathrm{a}$ & $086.5 \pm 10.8$ & c & $3.37 \pm 0.30$ & \\
\hline Kom. hib. TC & $107 \pm 28$ & $46.5 \pm 12.3$ & $\mathrm{ab}$ & $122.8 \pm 17.8$ & $\mathrm{ab}$ & $4.53 \pm 0.49$ & \\
\hline$p$ & $n s$ & * & & $* *$ & & $n s$ & \\
\hline \multicolumn{8}{|l|}{ Year } \\
\hline 2017 & $304 \pm 10$ & $07.6 \pm 0.9$ & c & $150.0 \pm 5.3$ & a & $4.00 \pm 0.13$ & $\mathrm{~b}$ \\
\hline 2018 & $108 \pm 13$ & $32.0 \pm 3.4$ & $\mathrm{~b}$ & $126.3 \pm 5.8$ & $\mathrm{~b}$ & $4.73 \pm 0.16$ & $\mathrm{a}$ \\
\hline 2019 & $147 \pm 06$ & $77.2 \pm 3.5$ & $\mathrm{a}$ & $074.3 \pm 5.9$ & c & $3.15 \pm 0.18$ & c \\
\hline$p$ & $* * *$ & $* * *$ & & $* * *$ & & $* *$ & \\
\hline
\end{tabular}

Mean values followed by same letters are not significantly different at the $5 \%$ level of probability; ${ }^{* *} p<0.001 ;{ }^{* *} p<0.01 ;{ }^{*} p<0.05 ; n s-$ not significant

ily determined by genotype, and dioecious varieties are typically characterized by both a higher stem height and a thicker basal stem diameter than monoecious varieties (Bennett et al., 2006; Amaducci et al., 2008; Cosentino et al., 2013). Indeed, the average stem height of six dioecious varieties in this study was $128.2 \mathrm{~cm}$ compared to $100.0 \mathrm{~cm}$ of four monoecious varieties and the average stem diameter of the dioecious varieties was $4.18 \mathrm{~mm}$ compared to $3.63 \mathrm{~mm}$ of the monoecious varieties. Furthermore, in the study by Baldini et al. (2018), USO 31 and Fedora 17 had a lower plant height than KC Dora, Futura 75 and Monoica. Amaducci et al. (2008) used the varieties Futura 75 and Tiborszallasi in their two-year study and reported an average stem height of 174 and $192 \mathrm{~cm}$, respectively, and an average stem diameter of $5.6 \mathrm{~mm}$ without statistically significant difference between the varieties. The values for both variables and both varieties are higher compared to our study, indicating that the growing conditions in our experiment were not optimal for hemp growth throughout the experimental period.

\subsection{THE CORRELATION ANALYSIS}

All six variables were used for the correlation analysis and all correlations were statistically significant, only the number of plants had no influence on the stem diameter
(Figure 3). The number of plants at harvest had a high correlation with the yield of dry stems (0.61). Tang et al. (2017) found that increasing plant density up to 240 plants $\mathrm{m}^{-2}$ also increases the stem yield. On the contrary, Amaducci et al. (2002) noticed that an increase in plant density meant only a small increase in the fresh and dry mass of the stems. Population density usually has a negative effect on the height of plants, as they compete for light and sources of nutrients (Legros et al., 2013). However, we found a positive but not very high correlation (0.40), probably due to the low number of plants at harvest in 2018 and 2019. The correlation analysis for the year 2017 alone showed a negative correlation (-0.27), but this was not statistically significant (data not shown). Tang et al. (2017) reported that stem height $(\mathrm{R} 2 \approx 0.9)$ and diameter $(\mathrm{R} 2 \approx 0.8)$ are strongly correlated with the yield of dry stems, which was also confirmed in our study. A high and negative correlation between weed biomass and stem yield (fresh or dry) was also observed, indicating the massive negative effect weeds have had on hemp production (see further discussion below).

\subsection{THE MEASURED VARIABLES WERE SIGNIFI- CANTLY INFLUENCED BY THE GROWING SEASON}

The year of production had a statistically significant 


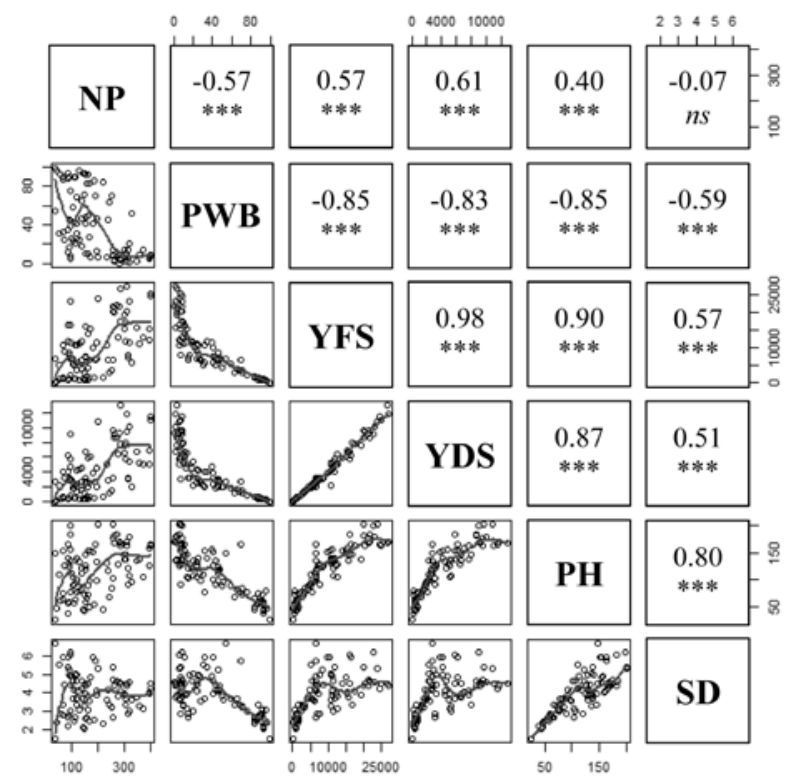

Figure 3: Correlation plots among 6 traits. NP - number of plants per $\mathrm{m}^{2}$ at harvest, PWB - proportion of weed biomass, YFS - yield of fresh stems, YDS - yield of dry stems, PH - plant height and SD - stem diameter; ${ }^{\star \star \star}$ indicates significance at 0.001 level of probability; ns - not significant

influence on all measured variables, which was already shown in Figure 2 and Table 3. The Figure 4 shows a detailed comparison of the impact of the production year expressed on an index scale. The year 2017 was the most favourable for hemp cultivation, where only the stem dimeter did not perform best compared to the other two years. In addition, the proportion of weed biomass was also the lowest. The year 2019 had the most adverse growing conditions, mainly due to the unfavourable arrangement of temperature and precipitation in May and June. The year 2018 was also less favourable due to high rainfall in midMay, which postponed sowing until the end of May, followed by low precipitation in June and high temperatures in July (Figure 1). The shorter growing season in 2018 due to late sowing had a negative effect on stem growth and thus on stem yield. The most pronounced negative effect of the hostile growing conditions of 2018 and 2019 is shown by the proportion of weed biomass, which was 4.2 and 10.2 times higher, respectively, compared to 2017. The correlation analysis also pointed to the significant negative impact of the biomass fraction of weeds on all measured variables, especially on stem yields. Since the test site and the agricultural technique used in the trials were the same in all three years, only the weather conditions could be the reason for the increase in the biomass proportion of weeds from 2017 to 2019. Jankauskiene et al. (2014) came to the same conclusions, finding a significant difference in the average density of weeds at full hemp emergence between two experiments carried out in two different growing pe- riods (2006-2007 and 2010-1012), but at the same testing location.

In the literature, hemp is described as a crop that requires little or no weed control during growth (Amaducci et al., 2015; Fike, 2016). However, there are very few scientific facts supporting this claim, as verified by Sandler \& Gibson (2018). These authors indicated that the reason for the lack of weed management in the majority of published, peer-reviewed studies could be the fact that hemp truly does not need active weed control. Furthermore, almost no mechanical or manual weeding was used in these studies. In the second scenario, which is more likely, the non-use of herbicides in hemp production could be related to the sensitivity of plants to many commonly used active compounds in herbicides. The authors concluded that hemp production should not be determined by weed manifestation and that detailed studies on weed intervention are needed to prevent yield losses. Our study confirmed that weeds can have a very strong negative impact on hemp performance, especially on the stem yield, which is the main concern when growing hemp for fibre production. Unfavourable weather conditions in 2018 and 2019 resulted in a low coverage of hemp plants per area (108 and 147 plants $\mathrm{m}^{2}$ at harvest for 2018 and 2019, respectively). This means that more space was available for weeds to develop and compete with hemp. Due to low number, the hemp plants could not close canopy area and were therefore overgrown by various weeds. The results of this study thus showed that weeds significantly reduced hemp stem yield 


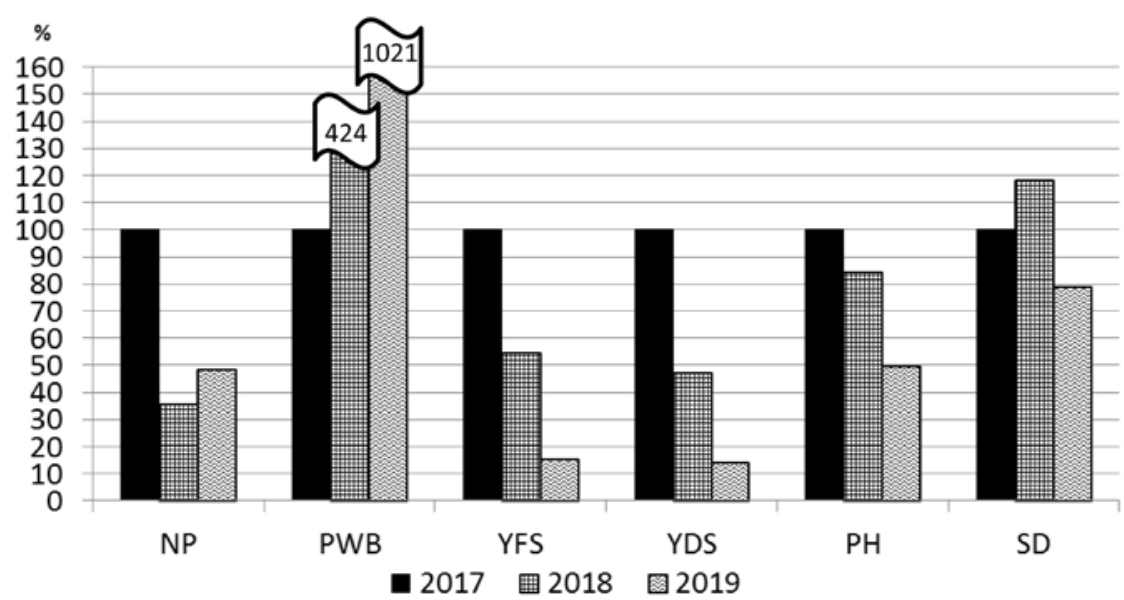

Figure 4: The comparison of the measured variables in relation to the year of the experiment, expressed on an index scale, with the year 2017 set at 100. NP - number of plants per $\mathrm{m}^{2}$ at harvest, PWB - proportion of weed biomass, YFS - yield of fresh stems, YDS yield of dry stems, $\mathrm{PH}$ - plant height and SD - stem diameter

and other variables under unfavourable weather conditions, most likely due to a lower number of hemp plants. Since no herbicide has yet been approved for the use of hemp in Europe (Legros et al., 2013; Sandler \& Gibson, 2018), active weed management for hemp cultivation under field conditions would be necessary in the future.

\section{CONCLUSIONS}

A three-year trial with 10 European hemp varieties showed that the dioecious varieties outperformed the monoecious varieties in terms of stem yields, plant height and stem diameter. The most productive variety in terms of fresh and dry stem yield was the dioecious variety Antal with $12.3 \mathrm{t} \mathrm{ha}^{-1}$ and $5.3 \mathrm{t} \mathrm{ha}^{-1}$, respectively. The year had a very strong influence on all measured variables; unfavourable weather conditions in 2019 (cold and wet May, hot and dry June) led to a sharp decline in all measured variables, including the lowest stem yields. In this year, the proportion of weed biomass was the highest. A highly negative and strongly statistically significant correlation between the biomass of weeds and the yield of the stems showed that weeds can strongly affect the production of hemp. Under the unfavourable weather conditions, when the hemp plants do not cover canopy due to low number of plants and are therefore not able to compete with fast growing weeds, effective weed management would be even more necessary.

\section{ACKNOWLEGEMENT}

This research was performed within the Target $\mathrm{Re}$ - search Programme V4-1611 and supported by grants from the Ministry of Agriculture, Forestry and Food and Slovenian Research Agency.

\section{REFERENCES}

Amaducci, S., Errani, M., \& Venturi, G. (2002). Response of hemp to plant population and nitrogen fertilisation. Italian journal of agronomy, 6(2), 103-112.

Amaducci, S., Scordia, D., Liu, F. H., Zhang, Q., Guo, H., Testa, G., \& Cosentino, S. L. (2015). Key cultivation techniques for hemp in Europe and China. Industrial Crops and Products, 68, 2-16. http://dx.doi.org/10.1016/j.indcrop.2014.06.041

Amaducci, S., Zatta, A., Pelatti, F., \& Venturi, G. (2008). Influence of agronomic factors on yield and quality of hemp (Cannabis sativa L.) fibre and implication for an innovative production system. Field Crops Research, 107(2), 161-169. https://doi.org/10.1016/j.fcr.2008.02.002

Baldini, M., Ferfuia, C., Piani, B., Sepulcri, A., Dorigo, G., Zuliani, F., Danuso F., \& Cattivello, C. (2018). The performance and potentiality of monoecious hemp (Cannabis sativa L.) cultivars as a multipurpose crop. Agronomy, 8(9), 162. https://www.mdpi.com/2073-4395/8/9/162

Barron, A., Coutinho, J., English, A., Gergely, S., \& Lidouren, E. (2003). Ecological agriculture I: Integrating hemp in organic farming system: A Focus on the United Kingdom, France and Denmark. København: The Royal Agricultural and Veterinary University.

Bennett, S. J., Snell, R., \& Wright, D. (2006). Effect of variety, seed rate and time of cutting on fibre yield of dew-retted hemp. Industrial crops and products, 24(1), 79-86. https:// doi.org/10.1016/j.indcrop.2006.03.007

Berenji, J., Sikora, V., Fournier, G., \& Beherec O. (2013). Genetics and selection of hemp. In P. Bouloc, S. Allegret \& A. Laurent (Eds.), Hemp: industrial production and uses (pp48-71). Wallingford, Boston: CABI. 
Bócsa, I. (1999). Genetic improvement: Conventional approaches. In: P. Ranalli (Ed.), Advances in hemp research (pp. 153-184). New York: The Haworth Press.

Bócsa, I., \& Karus, M. (1998). The Cultivation of Hemp: Botany, Varieties, Cultivation and Harvesting. Nashville, Vaughan Printing.

Cosentino, S. L., Test, G., Scordia, D., \& Copani, V. (2012). Sowing time and prediction of flowering of different hemp (Cannabis sativa L.) genotypes in southern Europe. Industrial crops and products, 37(1), 20-33. http://dx.doi. org/10.1016/j.indcrop.2013.07.059

Cromack, H. T. H. (1998). The effect of cultivar and seed density on the production and fibre content of Cannabis sativa in southern England. Industrial crops and products, 7(2), 205-210.

Elfordy, S., Lucas, F., Tancret, F., Scudeller, Y., \& Goudet, L. (2008). Mechanical and thermal properties of lime and hemp concrete (hempcrete) manufactured by a projection process. Construction and Building Materials, 22(10), 2116 2123. https://doi.org/10.1016/j.conbuildmat.2007.07.016

Fike, J. (2016). Industrial hemp: renewed opportunities for an ancient crop. Critical Reviews in Plant Sciences, 35(5-6), 406-424. https://doi.org/10.1080/07352689.2016.1257842

Flajšman, M., Kocjan Ačko, D., \& Čeh, B. (2018). Characteristics of common hemp varieties that are grown in Slovenia. Hop Bulletin, 25, 44-58.

Hennik, S. (1994). Optimisation of breeding for agronomic traits in fibre hemp (Cannabis sativa L.) by study of parentoffspring relationships. Euphytica, 78, 69-76.

Ihempfarms. (2019). WWW Document. URL www.ihempfarms.com/ (accessed January 2020).

Jankauskienè, Z., Gruzdevienè, E., \& Lazauskas, S. (2014). Potential of industrial hemp (Cannabis sativa L.) genotypes to suppress weeds. Zemdirbyste-Agriculture, 101(3), 265-270. https://doi.org/10.13080/z-a.2014.101.034

Karus, M., \& Vogt, D. (2004). European hemp industry: cultivation, processing and product lines. Euphytica, 140, 7-12.

Kraenzel, D. G., Petry, T. A., Nelson, B., Anderson, M. J., Mathern, D., \& Todd, R. (1998). Industrial hemp as an alternative crop in North Dakota. Institute for natural Resources and Economic Development (INRED). Agricultural Economics Report, 402.

Legros, S., Picault, S., \& Cerruti, N. (2013). Factors Affecting the Yield of Industrial Hemp - Experimental Results from France. In P. Bouloc, S. Allegret \& A. Laurent (Eds.), Hemp: industrial production and uses (pp- 72-97). Wallingford, Boston: CABI.

Mandolino, G., \& Carboni, A. (2004). Potential of marker-as- sisted selection in hemp genetic improvement. Euphytica, 140, 107-120.

Mediavilla, V., Leupin, M., \& Keller, A. (2001). Influence of the growth stage of industrial hemp on the yield formation in relation to certain fibre quality traits. Industrial Crops and Products, 13(1), 49-56.

R Core Team. (2016). R: A Language and Environment for Statistical Computing. Vienna, Austria: R Foundation for Statistical Computing. URL https://www.R-project.org/ (accessed January 2020).

Ranalli, P. (1999).Agronomical and physiological advances in hemp crops. In: P. Ranalli (Ed.), Advances in hemp research (pp. 61-84). New York: The Haworth Press.

Salentijn, E. M., Zhang, Q., Amaducci, S., Yang, M., \& Trindade, L. M. (2015). New developments in fiber hemp (Cannabis sativa L.) breeding. Industrial crops and products, 68, 32-41. https://doi.org/10.1016/j.indcrop.2014.08.011

Sandler, L. N., \& Gibson, K. A. (2019). A call for weed research in industrial hemp (Cannabis sativa L). Weed Research, 59(4), 255-259. https://doi.org/10.1111/wre.12368

Schäfer, T., \& Honermeier, B. (2006). Effect of sowing date and plant density on the cell morphology of hemp (Cannabis sativa L.). Industrial Crops Products, 23, 88-98. https://doi. org/10.1016/j.indcrop.2005.04.003

Schultes, R.E. (1970). Random thoughts and queries on the botany of Cannabis. In: C.R.B., Joyce, \& S.H., Curry (Eds.), The Botany and Chemistry of Cannabis (11-38). London: J. \& A. Churchill.

Struik, P. C., Amaducci, S., Bullard, M. J., Stutterheim, N. C., Venturi, G., \& Cromack, H. T. H. (2000). Agronomy of fibre hemp (Cannabis sativa L.) in Europe. Industrial Crops and Products, 11(2), 107-118.

Tang, K., Struik, P. C., Yin, X., Calzolari, D., Musio, S., Thouminot, C., Bjelková, M., Stramkale, V., Magagnini, G., Amaducci, S. (2017). A comprehensive study of planting density and nitrogen fertilization effect on dual-purpose hemp (Cannabis sativa L.) cultivation. Industrial Crops and Products, 107, 427-438. https://doi.org/10.1016/j.indcrop.2017.06.033

Tang, K., Struik, P. C., Yin, X., Thouminot, C., Bjelková, M., Stramkale, V., \& Amaducci, S. (2016). Comparing hemp (Cannabis sativa L.) cultivars for dual-purpose production under contrasting environments. Industrial Crops and Products, 87, 33-44. http://dx.doi.org/10.1016/j.indcrop.2016.04.026

Van der Werf, H. (1994). Crop physiology of fibre hemp (Cannabis sativa L.). $\mathrm{PhD}$ thesis. Wageningen: Agricultural University. 